\title{
Teaching Non-English-Majored College Students Listening and Speaking Through Multimedia and Network
}

\author{
Wu Heping, Zhao Jinchuan, Fan Rongping, Su Zhenli \\ College of Foreign Languages Hebei Normal University of Science \& Technology Qinhuangdao, China
}

\begin{abstract}
In recent years, multimedia and network have been widely applied to the teaching of listening and speaking on non-English-majored college students. In this article, the current situation of the teaching of listening and speaking in Chinese universities was analyzed, then, the advantages of multimedia and network were illustrated. Based on the problems that were found, some strategies were put forward to make the teaching more effective.
\end{abstract}

Index Terms: Multimedia and network; listening and speaking; non-English-majored college students

(C) 2013 Published by MECS Publisher. Selection and/or peer review under responsibility of the International Conference on E-Business System and Education Technology

\section{INTRODUCTION}

The College English Curriculum Requirements, modified by the Ministry of Education in 2007, illustrates that: “The objective of College English is to cultivate students' abilities of comprehensive applications of English, especially listening and speaking abilities, so that they can communicate effectively both in oral and written English in their study and social interaction in the future."[1] It also puts forward that the multi-media and network technology should be applied to improve the quality of teaching in listening and speaking, to stimulate students' learn autonomy and form their personalities.

English listening and speaking abilities are the priorities of college English teaching, and more and more English teachers begin to apply multimedia and network to assist their teaching. However, in listening and speaking classes, listening is more focused and speaking is placed in the second place; and in many colleges and universities, multimedia and network are only used as the methods, not the way to provide an environment to stimulate students' learner autonomy.

The article is to first analyze the current situation of the teaching of listening and speaking in college English, then gives the theoretical basis and advantages of the two approaches, so as to put forward some strategies so solve the problems and improve the quality of college English teaching.

Supported by Humanistic and Social Sciences Project of Hebei Education Department, China

* Corresponding author:

E-mail address: sunshine801@126.com 


\section{Current situation of the teaching of listening and speaking on non-English majored college students}

\section{A. The teachers' factor}

Recently, more and more English teachers have been conscious enough to stimulate students' interest in listening and speaking, and they try every method to motivate students in listening classes. However, though interactive teaching and learning are stressed, the listening classes are mostly teacher-centered, and students are still the passive receivers, thus their creativity and initiatives are overlooked. The application of multimedia and network only adds more chances of showing knowledge to the students, and most teachers can not really provide suitable language environments to the students under the help of these two approaches. Besides, teachers pay more attention to listening. They use $4 / 5$ of class time to play the listening materials and use the time left to check students' answers and explain the difficult language points, but they seldom provide opportunities for students to speak. In this way, the input (listening) process is realized, but the output (speaking) process is rarely conducted.

\section{B. The students' factor}

For most non-English majored college students, English is only a subject. Even though they spend much time on English study, their sole purpose is to pass College English Test (CET) Band 4 and 6. They know the importance of listening, but they always neglect speaking; they spend some time practicing listening, but they find it hard to insist on it. A lot of students listen to English materials only when they are having English classes, and even though they can not understand, they are reluctant to ask teachers questions. Some teachers don't want to admit such a phenomenon, but this is happening in English listening classes. Therefore, what students have learned is still “dumb” English, though they have learned a great amount of knowledge about English, they are not competent in real world communication.

\section{The environment factor}

The ideal number of students in an English class is less than 20. But in China, because of the limitations of the teaching conditions, there are more than 50, even more than 60 students in one class. Such a large-sized class is not beneficial for teachers' teaching and students' learning. In addition, the teaching materials are too literary oriented and lack authentic communicative factors. Some textbook writers notice this problem and they have made efforts to change the situation, but these changes can not keep pace with the development of the society.

\section{Theoretical Basis}

\section{A. Constructivism}

Formalization of the theory of constructivism is generally attributed to Jean Piaget, who articulated mechanisms by which knowledge is internalized by learners. He suggested that through processes of accommodation and assimilation, individuals construct new knowledge from their experiences [2]. When individuals assimilate, they incorporate the new experience into an already existing framework without changing that framework. This may occur when individuals' experiences are aligned with their internal representations of the world, but may also occur as a failure to change a faulty understanding. The fundamental traits of constructivism are autonomy, contextualization and socialization, it emphasizes that students are the center of the learning process, but meanwhile, teachers' role should not be neglected. Students are the main body of processing information, and they are the constructors of the ability of learning foreign languages. Teachers are the instructors of the learning process, they help to promote the construction of the learning environment. 
Constructivism focuses on the construction of a learning environment. With the infiniteness of multimedia technology and endless online information, both multimedia and network provide good audio, visual, tactile, psychological and cognitive environments for the construction of listening and speaking practice.

\section{B. Krashen's Input Hypothesis}

Krashen's Input Hypothesis is one of the theories of studying second language acquisition. Krashen believes that "humans acquire language in only one way — by understanding message or by receiving 'comprehensible input'”[3]. Second language acquisition takes place when a learner understands input that contains grammatical forms that are at " $\mathrm{i}+1$ ". He suggests the right level of input is attained automatically when interlocutors succeed in making themselves understood in communication. Students' attention should be focused on meaning rather than forms. This hypothesis explains how second language acquisition takes place, and it has great significance in directing the teaching of listening and speaking at colleges.

\section{The application of multimedia and network in the teaching}

\section{A. Advantages of multimedia and network}

Multimedia is media and content that uses a combination of different content forms. Multimedia technology provides a learner friendly and interactive learning environment for the students. With both visual and audio stimulation, it integrates various materials into a whole and shows them on the screen, making the knowledge easier to understand. It is not only beneficial for students' active exploration of knowledge, but also helpful to develop their associational thoughts.

Network serves as a supplementary tool to give students larger room to study autonomously. Under the network environment, students can choose learning materials according to their own will, their activeness and creativeness can be cultivated, thus passive in-class learning can be changed into autonomous out-of class learning.

Multimedia and network teaching breaks the limitation of synchronic learning and motivates students to focus their attention on the vivid listening and speaking materials, so that students' eagerness of pursuing study can be stimulated, and this will become a inner power to push them forward.

Figure 1 shows a student-centered teaching mode taking multimedia and network as the teaching assistance:

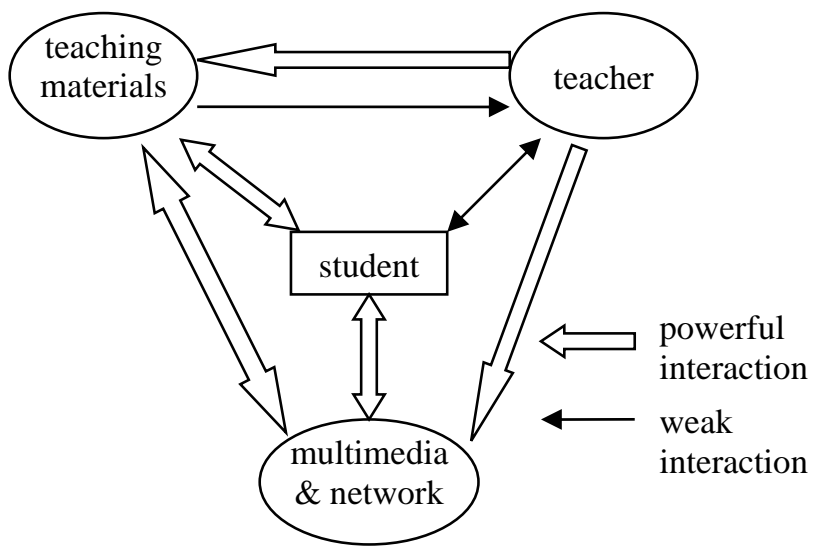

Figure 1 A student-centered teaching mode 


\section{B. Strategies of improving the teaching quality through multimedia and network}

With so many advantages, multimedia and network have been widely used in the teaching of listening and speaking in colleges. How can the teaching be more effective? The strategies are as follows:

1) Transforming teachers' role, making them more qualified: Under the new circumstances, teachers should be instructors rather than class controllers. Their major task is to design the teaching process according to the rules of language. Therefore, teachers are facing many new challenges. On one hand, they must be skillful in operating the multimedia and network system; on the other hand, they have to spend more time exploring new approaches of teaching. Meanwhile, they should also improve their own knowledge structure and teaching level. In this respect, they should enrich their knowledge scale, actively applying multimedia and network technology to their everyday teaching, especially using materials got from the Internet and courseware they made in their teaching practice. By practicing more, their skills of operating abilities can be promoted.

2) Practicing step by step, cultivating students' learner autonomy: Since students come from different areas, even different provinces of China, they have quite different learning experiences before entering the college. Therefore, it is necessary for teachers to give them correct directions. The first step is to correct pronunciation [4]. For non-English-majored college students, the class time is limited. However, teachers can distribute recordings to students for them to practice after class. By listening more and imitating more, students will be active to learn by themselves, and their learner autonomy can be cultivated. Gradually, they can listen to more complicated materials, such as recordings of Listen To This, or Step by Step, which are used for English majors. After that, they can go even further to listen to VOA special English, or BBC news, until they are able to watch English movies and totally understand them. During the whole process, teachers are not relaxed, though. They should adjust their teaching methods according to students' performance. That means, they should not only focus on students' feedback during class time, but also how they practice and perform after class. Here, QQ, MSN, or blogs can become very good tools for teachers to exchanges thoughts with students. Teachers can also paste the listening and speaking tasks in their QQ spaces and blogs for students to practice, then on the basis of discussion, they answer students' questions and direct them to find the correct ways of practicing. Because teaching through multimedia and network is based on students' learner autonomy, it provides an open environment to students, which contains many approaches and ways of learning knowledge.

3) Integrating the multimedia and network environment with humanistic environment, forming a harmonious teaching environment: After a period of time has passed, students' interest in the new teaching environment may fade away. They may feel the "coldness" when listening via computers or speaking to these machines, which lack humanistic care and emotional communication. This is especially felt during the oral practice, which needs more person to person communication. Therefore, while providing a good environment for students to speak, and presenting materials for them to listen to, teachers should act according to circumstances to combine human-machine communication with teacher-student communication and communication between students. So that students' sense of belonging can be generated, and they can maintain their enthusiasm in studying until they finally achieve their goals. Teachers can integrate class time and after-class time into a whole and organize various learning activities, such as peer study, group discussion, and presentation, to direct students to evaluate for themselves and solve problems they find.

\section{Conclusion}

Multimedia and network teaching has become an effective way to improve English teaching and study. Applying colorful multimedia and network resources to the teaching of listening and speaking can greatly stimulate students' enthusiasm and practice their listening and speaking abilities. Teachers should also improve 
their teaching skills and be qualified enough to make the teaching process alive, so that a good teaching and learning atmosphere can be formed.

\section{Acknowledgment}

I’m grateful for my colleague Shao Lijun and Liu Honggang, for their constructive suggestions.

\section{References}

[1] “The College English Curriculum Requirements,” Ministry of Education of the People’s Republic of China, 2007. (in Chinese)

[2] Garrison, J. “Constructivism and Education,” Cambridge University Press, Cambridge, UK, pp. 68-81, 1998.

[3] Krashen, S. The Input Hypothesis: Issues and Implications. London: Longman, 1985.

[4] H. Zeng, "The current situation and ponderation of multi-media teaching in college English listening and speaking course”, Computer knowledge and technology, Vol. 5, pp. 2959-2560, April 2009. (in Chinese) 